University of Louisville

ThinkIR: The University of Louisville's Institutional Repository

8-2011

\title{
Contribution of the Rv1985c transcriptional regulator to Mycobacterium tuberculosis intracellular adaptation.
}

Nicholas B. Wantland 1984-

University of Louisville

Follow this and additional works at: https://ir.library.louisville.edu/etd

\section{Recommended Citation}

Wantland, Nicholas B. 1984-, "Contribution of the Rv1985c transcriptional regulator to Mycobacterium tuberculosis intracellular adaptation." (2011). Electronic Theses and Dissertations. Paper 1527.

https://doi.org/10.18297/etd/1527

This Master's Thesis is brought to you for free and open access by ThinkIR: The University of Louisville's Institutional Repository. It has been accepted for inclusion in Electronic Theses and Dissertations by an authorized administrator of ThinkIR: The University of Louisville's Institutional Repository. This title appears here courtesy of the author, who has retained all other copyrights. For more information, please contact thinkir@louisville.edu. 
CONTRIBUTION OF THE RV1985C TRANSCRIPTIONAL REGULATOR TO MYCOBACTERIUM TUBERCULOSIS INTRACELLULAR ADAPTATION

Nicholas B. Wantland

B.S., University of Louisville, 2006

\author{
A Thesis \\ Submitted to the Faculty of the \\ In Partial Fulfillment of the Requirements \\ For the Degree of \\ Master of Science \\ Department of Oral Biology \\ School of Dentistry \\ University of Louisville \\ Louisville, Kentucky
}

Graduate School of the University of Louisville

August 2011 

CONTRIBUTION OF THE RV1985C TRANSCRIPTIONAL REGULATOR TO MYCOBACTERIUM TUBERCULOSIS INTRACELLULAR ADAPTATION

Nicholas B. Wantland

B.S., University of Louisville, 2002

Thesis Approved on

$$
\text { July } 29,2011
$$

by the following Thesis Committee

$\frac{\text { Dr. James E. Graham (Chairman) }}{\text { Dr. David A. Scott }}$
$\frac{\text { Dr. DOrald R. Demuth }}{}$




\begin{abstract}
DEDICATION
I would like to dedicate this work to my parents, without their continued support and encouragement, none of this would have been possible.
\end{abstract}




\section{ACKNOWLEDEGMENTS}

My deepest gratitude goes out to Dr. James E. Graham for his support and guidance during this project. He has always been a valuable source of information and provided me with anything that I needed. Without his direction, I doubt this project would have been successful. I am very fortunate to be a member of his lab.

A great amount of thanks goes out to Dr. Mohammad A. Alzohairy for his work creating the recombinant Rv1985c strains, as well as his assistance with this project.

I want to extend my appreciation to my committee members Dr. Donald R. Demuth and Dr. David A. Scott for their time and valuable insight over the past two years.

I want to thank Terry P. Manning and the McLeish Laboratory for the donor cells used in all the macrophage experiments.

Finally, I want to thank the Microbiology \& Immunology Department and Oral Biology Department for making the past two years an enjoyable experience and creating a wonderful place to learn. 


\begin{abstract}
CONTRIBUTION OF RV1985C TO MYCOBACTERIUM TUBERCULOSIS INTRACELLULAR ADAPTATION

Nicholas B. Wantland

July 29, 2011
\end{abstract}

\begin{abstract}
Mycobacterium tuberculosis causes the often-fatal infectious disease Tuberculosis, and infects approximately one third of the world's population. Gaining a better understanding of how these bacteria regulate gene expression for intracellular survival will likely aid in developing ways to reduce disease. Studies of bacterial RNA expression in experimentally infected primary human macrophages indicated open reading frame Rv1985C, encoding a putative transcriptional regulator, may contribute to intracellular survival. Comparison of a strain constitutively expressing Rv1985c and the isogenic wildtype parent by array hybridization identified genes potentially regulated by Rv1985c. These included a group encoding factors likely relevant to cell wall remodeling,
\end{abstract}


particularly modification of mycolic acids. Interestingly, of the 22 upregulated genes identified by significance analysis of microarray, S.A.M., among the highest expressed were some of those previously described as part of the DosR/DevR dormancy regulon. We verified that Rv1985C mRNA levels rose dramatically in the first 24 hours following phagocytosis, and confirmed a lack of increased dosR/devR transcription in the constitutively expressing Rv1985C strain. Finally we showed that a Rv1985c knock out mutant while able to grow normally in laboratory broth had reduced ability to colonize cultured human macrophages, and showed reduced cytopathic effects. Restoring $R V 1985 \mathrm{C}$ reversed this attenuation of the mutant. 


\section{TABLE OF CONTENTS}

ACKNOWLEDGMENTS .........................iv

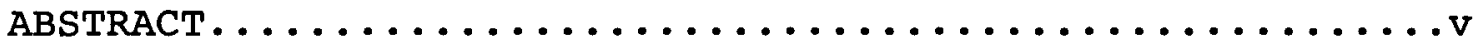
LIST OF FIGURES.......................... CHAPTER I:

INRODUCTION

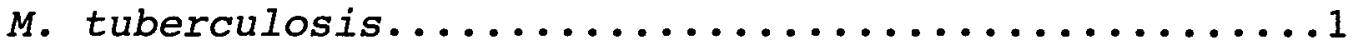

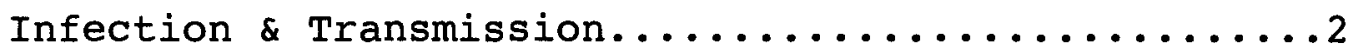
Epidemiology ..........................

Gene Regulation........................4 Wayne Model Shiftdown.....................4 DevR/DosR and Hypoxic Response................ Hypothesis........................... CHAPTER II:

MATERIALS AND METHODS

Mycobacterium tuberculosis Strains and Media......6 RNA Purification.......................

DNase Treatment....................... cDNA synthesis........................ Array Hybridization.......................

Quantitative Real-Time PCR Analysis.............11

Culturing of Macrophages...................11 
Cell Culture Infection Model................14

Kinyoun Staining Procedure.................. 14

Harvesting of M. tuberculosis From Macrophage

Monolayers.............................. 15

Biohazard and Laboratory Safety..............16

CHAPTER III:

RESULTS

Improved RNA Purification................. 17

Microscopic Analysis of Rv1985c.............17

RT-qPCR Analyses of Rv1985c during macrophage

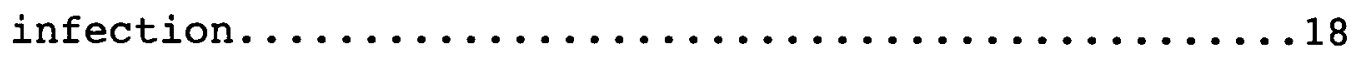

Array Hybridization of Rv1985c+ RNA...........19

CHAPTER IV:

DISCUSSION

Desaturases and Mycolic Acid Modification.........36

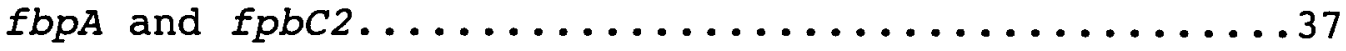

Alph-crystallin.........................

Rv1985c may bind dnaA.......................

Increased $R V 1985 C$ expression in response to

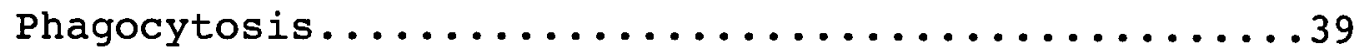

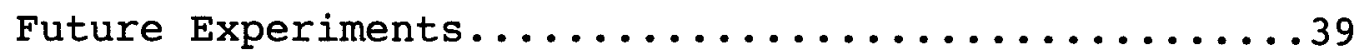

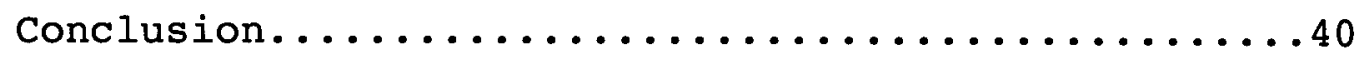

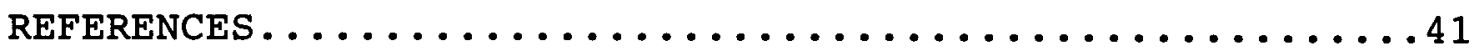

CURRICULUM $\operatorname{VITAE} \ldots \ldots \ldots \ldots \ldots \ldots \ldots \ldots \ldots \ldots \ldots \ldots$ 


\section{LIST OF FIGURES}

1. RNA purification nondenaturing agarose gel.........23

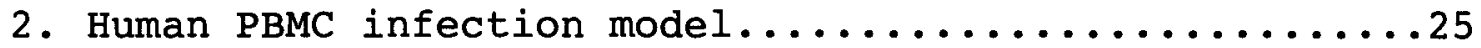

3. Rv1985C contributes to uptake and early

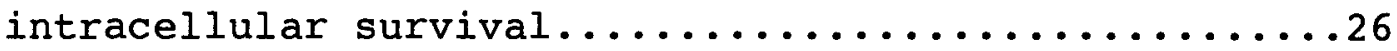

4. Cells infected by the RV1985c mutant show better survival in the infection model...............28

5. Rv1985c contributes to intracellular growth........29

6. Rv1985c mRNA levels increase on phagocytosis........30

7. Changes in mRNA levels with constitutively expressed $R v 1985 c \ldots \ldots \ldots \ldots \ldots \ldots \ldots \ldots \ldots \ldots \ldots \ldots \ldots$

8. Representative array hybridization image........... 32 
CHAPTER I

\section{INTRODUCTION}

M. tuberculosis:

Mycobacterium tuberculosis is the causal agent of the often-fatal infectious disease Tuberculosis. Even though a vast amount of information has been gathered on M. tuberculosis, fist isolated and characterized by Koch in 1882 , it remains one of the largest and most widespread infectious diseases on earth. It is a nonmotile, rod shaped, predominantly intracellular pathogen with an approximately 18-20 hour doubling time. The species is characterized as acid-fast bacteria due to its ability resist decolorization by acid-alcohol after staining with aniline dye. This characteristic is due to the high concentration of lipids embedded in its cell wall, including the wax-like mycolic acids. While there are numerous $M$. tuberculosis strains the best characterized is $\mathrm{H} 37 \mathrm{Rv}$. Its genome consists of 3,924 open reading frames (ORFs) and a $65 \% \mathrm{G}+\mathrm{C}$ content (Cole et al., 1998). These bacteria primarily infect the host 
respiratory tract and initially infect resident alveolar macrophages.

\section{Infection \& Transmission:}

The main portal of entry for $M$. tuberculosis is through the respiratory tract. Infection by M. tuberculosis usually begins with the inhalation of the bacteria in the form of airborne droplets. They must then travel through the respiratory tract to the lung where they are phagocytosed by host alveolar macrophages (Russell et al., 2001). If falling on the epithelium of the upper airway the bacteria are swallowed and destroyed in the G.I. tract. If the macrophages have been previously activated they can eliminate the bacteria but if not the bacteria persist and replicate inside these host cells. Next a granuloma or tubercle is formed by the recruitment of mononuclear cells from the surrounding blood vessels. At this stage an effective T-cell response contains the bacteria in a microscopic granule and is known as the latent stage where there are no outward signs of disease, and there is no transmission of bacteria from the host to others (Russell et al., 2001) During this stage the bacteria are thought to be less active or in a state of non-replicating persistence 
(NPR). Due to changes in the host, HIV, old age, malnutrition, or other circumstances that alter the host's immune system, the infection can again become active. The bacteria then escape from growing granulomas that merge with airways, liquefy, and spill out into the bronchial passages. This leads to a cough that expels bacteria from the lung into the external environment spreading the bacteria to a new host (Russell et al., 2001)

\section{Epidemiology :}

According to the World Health Organization, approximately one third of the world's population is infected with the $M$. tuberculosis and in 2009 it accounted for 1.7 million deaths worldwide. The highest rates of new infections are found in Africa, South-East Asia, and the East Mediterranean.

Recent globally increasing numbers of HIV infected persons has also led to an increase in cases of active tuberculosis. A person who is infected with HIV and M. tuberculosis is many more times likely to have active disease then someone without a HIV infection, as the virus targets CD4+ T-cells essential for the control of M. tuberculosis infection. 


\section{Gene Regulation:}

During the course of infection $M$. tuberculosis encounters a wide range of environments all of which exert different pressures and stresses on the bacterial cell. Inside the host bacteria must be able to resist the actions of reactive nitrogen and oxygen species as well as lowered $\mathrm{pH}$ and potentially toxic free fatty acids. They must also withstand the antimicrobial action of alveolar surfactant as well as hypoxic conditions when inside a granuloma. Outside of the host, during transmission $M$. tuberculosis must then face other pressures such as UV light, low temperature, desiccation, and starvation (Manganelli et al., 2004). The bacteria must have means to regulate expression of its large genome to survive in these diverse environments. Approximately $5 \%$ of $\mathrm{H} 37 \mathrm{Rv}^{\circ}$ 's genome, 190 genes, is predicted transcriptional regulators that facilitate this process.

\section{Wayne Model shiftdown:}

wayne et al., 1996, showed that bacteria when abruptly transferred from vigorously aerated cultures to anaerobic conditions quickly died but when gradually shifted to these conditions showed increased tolerance and survival. These cells where said to be in a nonreplicating persistent 
state. Upon aeration the bacteria began growing again. This effect was later described as being controlled by the DevR/DosR regulon.

\section{DevR/DosR and Hypoxic Response:}

The DevR/DosR regulon is known to be activated when the bacterial cell encounters hypoxic conditions as well as nitric oxide and carbon monoxide species (Park et al, 2003). This regulon consists of approximately 48 genes, with a core group of 4-6 genes that are found across all Mycobacteria (Gerasimova et al., 2011), which arrest growth and put the cell in a dormant/drug tolerant state (Chauhan et al., 2011).

\section{Hypothesis:}

Previous studies with experimentally infected Thp-1

cell line macrophages indicated open reading frame $R v 1985 C$, which encodes a putative lysR transcriptional regulator (zhou et al., 2010), contributes to the survival of the bacteria after phagocytosis. Genes that are under the control of this transcriptional regulator will contribute the survival of the bacteria during phagocytosis host by macrophages. 
CHAPTER II

\section{MATERIALS AND METHODS}

\section{Mycobacterium strains and Media:}

M. tuberculosis wild type strain, H37Rv (ATCC \#25618), was obtained from the American Type Culture collection. Dr. Mohammad A. Alzohairy created the RV1985C over expressing mutant strain by expressing $R v 1985 \mathrm{C}$ constitutively from the $M$. bovis hsp60 promoter. Alzohairy also created the $\Delta R V 1985 c$ knock-out mutant strain, as well as the complemented $\Delta R V 1985 c$ strain. All bacteria were grown from frozen stocks in 7 H9 Middlebrook media enriched with oleic acid, albumin, dextrose, and catalase (OADC) $1 \%$ Tween-80 at $37^{\circ} \mathrm{C}$ with shaking at $200 \mathrm{rpm}$ to mid-log density for all experiments.

\section{RNA Purification:}

RNA purification first began by growing M. tuberculosis strains to mid-log phase $(0.2$ OD at $600 \mathrm{~nm})$ as described. For larger RNA preparations, $20 \mathrm{ml}$ of mid-log culture was spun down in multiple $1.5 \mathrm{~mL}$ micro-centrifuge tubes in a refrigerated centrifuge, $-4^{\circ} \mathrm{C}$, at maximum speed 
for 10 minutes. Making sure to keep the bacteria on ice the supernatant was removed and discarded. The bacterial pellets were lysed with RTL buffer with a small amount of fresh dithiothreitol, DTT, powder added. The lysed bacteria were subsequently added to bead beater tubes containing zirconia-silica beads along with $5 u$ u of phenol as a disinfectant. The tubes were sealed with parafilm and heated $970^{\circ} \mathrm{C}$ for 1 minute; then placed into an ice bath and allowed to cool. Next the tubes were placed in a Forma FP120 bead beater to mechanically lyse the bacteria. The samples were agitated for four twenty second cycles at a maximum speed of six. Samples were then placed in an ice bath for 5 minutes in between bead beater cycles to prevent over heating. The bead beater tubes containing the samples were centrifuged at low speed for one minute to settle the zirconia-silica beads to the bottom of the tube allowing for easy removal of the RNA containing liquid. The liquid was removed and placed in a $2 \mathrm{~mL}$ centrifuge tube containing and equal volume of $100 \%$ ethanol. The samples were purified using Qiagen RNAeasy kit following manufacturer's instructions. The purified RNA now in nuclease free water was precipitated overnight at $-20^{\circ} \mathrm{C}$ using $2 \mathrm{x}$ volume $5 \mathrm{M} \mathrm{LiCl}$. 


\section{DNase Treatment:}

Centrifuging the sample containing LiCl precipitated RNA at maximum speed for 10 minutes to form a RNA pellet. The RNA pellet was washed twice with $70 \%$ ethanol and allowed to air dry. Then the pellet was resuspended in $200 \mathrm{uL}$ cold $\mathrm{H}_{2} \mathrm{O}$. To the resuspended RNA $20 \mathrm{uL}$ of $10 \mathrm{x}$ DNase buffer was added along with 10 uL Turbo DNase (Invitrogen). The sample was heated at $37^{\circ} \mathrm{C}$ for thirty minutes. To neutralize the reaction 20uL of EDTA was added and the sample heated at $75^{\circ} \mathrm{C}$ for 5 minutes. Following DNase treatment the sample was distributed in $5 \mathrm{ug}$ aliquots and precipitated with $2 x$ volume $95 \%$ ethanol and $0.75 x$ volume $\mathrm{NH}_{4} \mathrm{OAC}$. The samples were stored as precipitates at $-20^{\circ} \mathrm{C}$. cDNA synthesis:

Approximately 2.5-5ug of precipitated DNA free RNA in a nuclease free micro-centrifuge tube was centrifuged and washed twice with $70 \%$ ethanol. The ethanol was then removed and the pellet allowed to air dry or 3 minutes at $37^{\circ} \mathrm{C}$. To the RNA 1uL of random decamers primers were added along with luL of 10mM 4 dNTP $\mathrm{mix}$ and 13uL of $\mathrm{H}_{2} \mathrm{O}$. This mixture was heated at $65^{\circ} \mathrm{C}$ for five minutes and then allowed to incubate on ice for one minute. Contents of the tube were collected by centrifugation. Next 4 uL of a $5 x$ first strand DNA buffer (Invitrogen) was added along with 1uL 0.1M DTT, 
luL RNAse-out (Invitrogen), and luL superscript III (Invitrogen). The contents of the tube was mixed by pipetting the solution up and down. After that, the solution was allowed to incubate at room temperature for five minutes before being placed in a heat block at $50^{\circ} \mathrm{C}$ for 90 minutes. Finally, heating at $70^{\circ} \mathrm{C}$ for five minutes inactivated the reaction. The newly created CDNA was stored at $-20^{\circ} \mathrm{C}$ for future use in RT-qPCR.

\section{Array Hybridization:}

Approximately 25ug of DNA free RNA was spun down for 10 minutes at maximum speed in a $1.5 \mathrm{~mL}$ centrifuge tube. The RNA pellet was washed twice with $70 \%$ ethanol and allowed to dry for 3 minutes. 55uL of nuclease free water with $0.1 \mathrm{mM}$ EDTA was used to dissolve the pellet. Next 5uL decamers, 5 uL of $10 \mathrm{mM}$ dATP, dGTP, dTTP mix, 5uL $0.1 \mathrm{mM}$ dCTP, and 6.25uL p33 labeled dCTP was added to the dissolved RNA and the contents was heated at $65^{\circ} \mathrm{C}$ for 5 minutes; then allowed to incubate on ice for one minute. The content of the tube was collected by centrifugation; 20uL of $5 \mathrm{x}$ first strand buffer was added followed by $5 \mathrm{ul}$ of DTT $0.1 \mathrm{M}, 5 \mathrm{UL}$ RNAse out, and 5uL superscript III. The reaction was allowed to incubate at room temperature for 5 minutes followed by incubation at $50^{\circ} \mathrm{C}$ for 90 minutes. 
Heating the mixture at $70^{\circ} \mathrm{C}$ for 5 minutes inactivated the reaction.

Next a Sephadex G50 column was prepared by putting glass wool in the bottom of a syringe and then filling the syringe with G50 making sure there are no bubbles in the column. Next a few drops of $0.1 \mathrm{M} \mathrm{NaCl}$ was added to the column to make sure it is functioning properly. The radio labeled cDNA is then run through the column and drops are collected into micro-centrifuge tubes. Approximately 3 drops are collected per tube and around 15 tubes are necessary to completely run the sample. The radioactivity of the tubes is then measured. If the cDNA synthesis worked properly you will have one large peak of radioactive tubes. The three tubes with the highest radioactivity were combined and $\mathrm{NaOH}$ was added so that the final concentration of the solution $0.4 \mathrm{M} \mathrm{NaOH}$. Probes were heated to $55^{\circ} \mathrm{C}$ for 15 minutes to hydrolyze RNA template. The probe was then added to a glass tube containing the nylon array and hybridization solution consisting of $0.5 \%$ SDS, $6 x$ SSC, $5 x$ Denhard's solution, and $100 \mathrm{ug} / \mathrm{mL}$ salmon DNA. The array was allowed to hybridize overnight in a rotating incubator at a temperature of $65^{\circ} \mathrm{C}$.

Following the overnight incubation the array is then washed with a mixture of $0.1 \times S S C$ \& SDS. After washing the 
array was then placed on blotting paper and wrapped in plastic wrap. The array is exposed to a phosphorimaging plate, Fuji Film, for 24 hours before it is read by a phosphorimager and analyzed using Array Vision Software.

Quantitative real-time PCR analysis (RT-qPCR):

Primers were selected for sigA, sigE, RV1985C, Rv0195, fdxA, hspX, devRS \& devR by Primer 3 software (Table 1) and tested for equal efficiency relative to standard sigA primers using dilutions of genomic DNA template. Samples were analyzed utilizing a DNA Opticon 2 Monitor (MJ Research) and SYBR Green (Finnzymes) for RT-qPCR.

\section{Culturing of Macrophages:}

Peripheral blood mononuclear cells, PBMCs, were obtained from Terry Manning of the Mcleish Laboratory. They were centrifuged at 1,600 RPM for five minutes at room temperature in a $50 \mathrm{~mL}$ conical centrifuge tube to pellet the cells. The supernatant was removed and the cells were gently washed with $20 \mathrm{~mL}$ of phosphate buffered saline, PBS. Again the cells were centrifuged and washed with $20 \mathrm{~mL}$ of PBS. Next the PBMCs were under laid with $1 \mathrm{~mL}$ of heat inactivated fetal bovine serum, FBS, and left to sit for five minutes undisturbed as to allow any clumps to settle to the bottom of the tube. The top layer containing the PBMCs was removed, making sure to not disturb the serum 


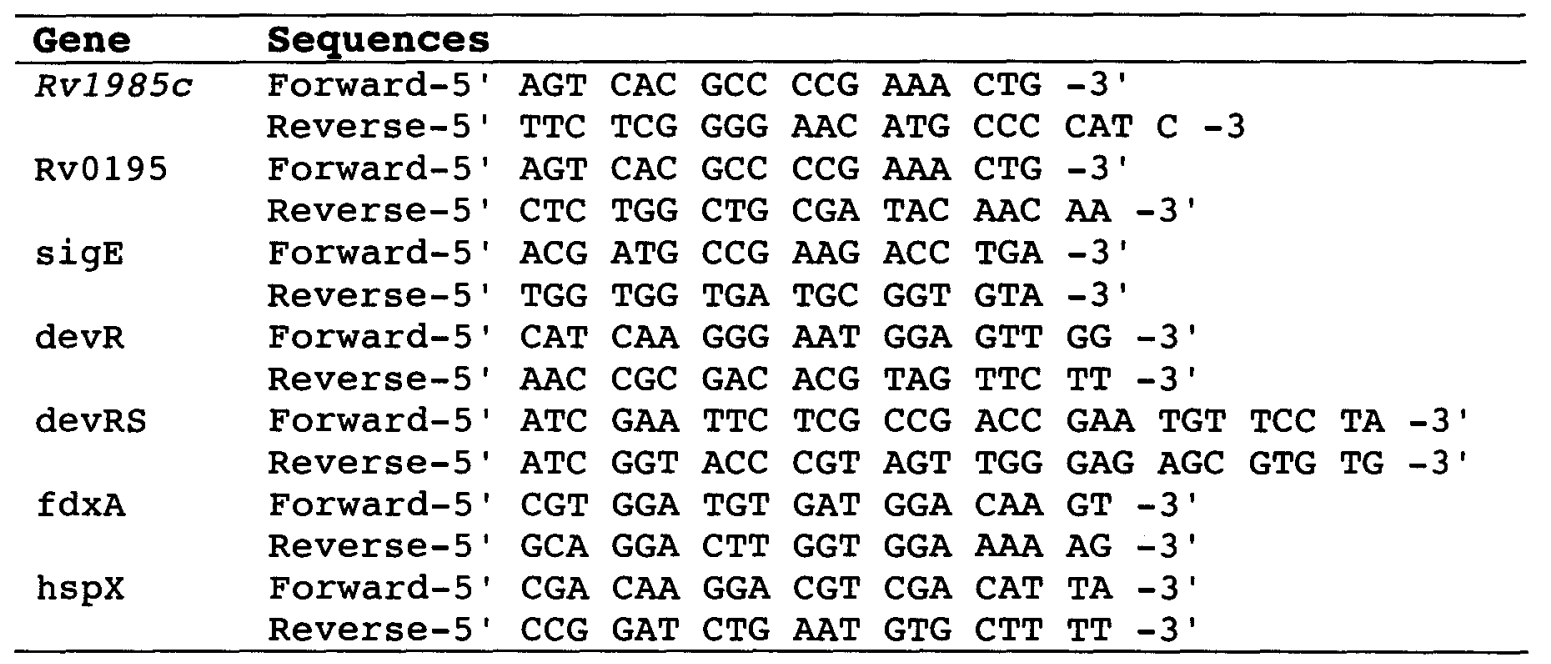

Table 1. Table of primers used for RT-qPCR measurements. 
layer, and placed in a new sterile centrifuge tube. The cells were once again centrifuged and the supernatant was removed. The PBMCs are then brought up in 15ml of RPMI 1640 containing, additional L-glutamine, $0.5 \%$ nonessential amino acids, $1 \%$ Hepes, and $5 \%$ heat inactivated FBS. The concentration of the cells was measured using trypan blue and a hemocytmeter and adjusted to $2 \times 10^{6} \mathrm{cells} / \mathrm{mL}$ by adding additional media. The cells were then placed in a Teflon bowl and allowed to sit undisturbed in a $37^{\circ} \mathrm{C}$ incubator for 5 days. After the five-day incubation the cells and media were removed and placed in 50mL conical centrifuge tube. Prewarmed PBS with $2 \%$ FBS is used to help wash the cells out of the Teflon bowl. A cell scraper was also used to help remove any adherent cells. The cells were spun down in a centrifuge at 1,600 RMP for 5 minutes. The supernatant was then removed and the cells were washed with $20 \mathrm{~mL}$ of PBS containing $2 \%$ FBS. Then the cells were brought up in the same RPMI media as before to a density of $5 \times 10^{6} / \mathrm{mL}$. One $\mathrm{mL}$ of media containing cells was added to each well of a chamber slide, for microscopic analysis, and $4 \mathrm{~mL}$ for each well in a six well plate, for RNA time course experiments. Allowing the cells to adhere for two days before removing non-adherent cells and washing with RPMI 
media. Next the media was replaced and the cells were ready for infection with $M$. tuberculosis.

\section{Cell Culture Infection Model:}

Bacteria were grown as shaking cultures as described above from frozen stocks. Before the infection the bacteria were placed in a $15 \mathrm{~mL}$ centrifuge tube along with a small amount of zirconia-silica beads and vortexed gently to disrupt clumps. The bacteria were then centrifuged at $300 \mathrm{rmp}$ with a 4 in rotor (Beckman) for 3 minutes to pellet any undisrupted clumps of bacteria leaving a single cell suspension. The bacteria were opsonized by incubation with an equal volume of non-inactivated FBS for 20 minutes before dilutions were made in RPMI with $2 \%$ FBS. Infections were carried out with a one to one MOI.

\section{Kinyoun Staining Procedure:}

Infection media was first removed followed by a wash with phosphate buffered saline. Each well of the chamber slide was then fixed with $0.5 \mathrm{ml}$ of a $3 \%$ formaldehyde solution and allowed to set for thirty minutes. After the thirty minute fixation the formaldehyde solution was removed and replaced with $0.5 \mathrm{ml}$ of cold methanol that had been placed in a $-80^{\circ} \mathrm{C}$ freezer for at least thirty minutes before use. The methanol was then allowed to sit on the slides for fifteen minutes. After the fifteen-minute soak 
the methanol was removed and the slides were allowed to air-dry before the upper portion of the chamber slide was removed. At this point the slide was heated at $75^{\circ} \mathrm{C}$ for thirty minutes to ensure the monolayer was "baked on" to the slide. The slide was then ready to be stained and must be done so as soon as possible to achieve the best staining results. If it had been a long period of time between the slide fixation and staining the slides were re-soaked in cold methanol and heat fixed before continuing with the staining.

The slides were then saturated with Kinyoun Carbol Fuchsin stain consisting of $1 \mathrm{~g}$ basic fuchsin, $2 \mathrm{~g}$ phenol crystals, $5 \mathrm{ml} 95 \%$ ethanol, \& $25 \mathrm{~mL}$ of $\mathrm{H} 20$ for 20 minutes to stain the bacteria. The slides were washed with $95 \%$ ethanol, DIFCO'S TB Quick Stain Reagent $B$, and $\mathrm{H}_{2} 0$ until the wash water ran clear. Next the slides were stained with $1 \%$ $\mathrm{w} / \mathrm{v}$ methylene blue for $20 \mathrm{~min}$ to stain the macrophage monolayer. The slides were rinsed with water to remove excess stain and allowed to air dry before being viewed under the microscope.

Harvesting of $M$. tuberculosis from macrophage monolayers:

The six well plates that contained the infected macrophage monolayers were removed from the incubator and placed on ice. The media was removed and the monolayers 
washed twice with prewarmed PBS before being lysed with 1\% Triton $x-100$. The contents of the well, which contained bacteria, Triton $\mathrm{x}-100$ and macrophage cell debris was collected in a $1.5 \mathrm{~mL}$ micro-centrifuge and spun at very low speed in a refrigerated centrifuge, $0^{\circ} \mathrm{C}$, for 10 minutes. This step pellets the macrophage debris while still leaving the bacteria in suspension. The supernatant was removed to a new centrifuge tube that was then spun at maximum speed in the same centrifuge for 10 minutes to pellet the bacteria. The liquid on top of the bacterial pellet was discarded and the bacteria lysed as described previously in the RNA purification procedure. Biohazards and laboratory safety:

M. tuberculosis is a Class 3 biohazardous agent. All experiments with live $M$. tuberculosis were performed in the certified BSL3 facility of Dr. James E. Graham in the Department of Microbiology and Immunology at the University of Louisville. Nicholas B. Wantland was trained in the relevant safety practices. 


\section{CHAPTER III}

\section{RESULTS}

\section{Improved RNA Purification:}

Obtaining pure stable RNA is essential for achieving proper results when performing array hybridizations as well as with RT-qPCR. I tried various methods to determine which would yield the highest quality RNA. After numerous trials the best method involved lysis with RLT buffer (Qiagen RNeasy mini kit) with DTT added, followed by “bead beating" with silica-zirconium beads and the use of silica column binding. The captured RNA was then precipitated overnight with LiCl at $-20^{\circ} \mathrm{C}$ before undergoing a DNAse treatment and second precipitation with ethanol-ammonium acetate (Figure 1 ).

Microscopic Analysis of Rv1985c:

Separate macrophage monolayer cultures (Figure 2) were infected with H37Rv, $\Delta R v 1985 c, \& \Delta R V 1985 c+R v 1985 c$ strains at a 1:1 MOI and examined at $24,48,72$, and 96 hours post infection. While all macrophage cultures were equally inoculated amounts the $\Delta R v 1985 c$ mutant showed a significant decrease in its uptake and early survival (Figure 3) 
indicating $R V 1985 \mathrm{C}$ plays an important role in the early infection process. Plating of the inocula media and washes showed very few colonies, suggesting more than $90 \%$ of the inocula bacteria were phagocytosed and destroyed. Factors contributing to survival are therefore likely needed during this initial infection in this model.

There was also a substantial loss in the macrophage monolayer over the course of 96 hours in the wild type and the complemented $\Delta R V 1985 C$ (Figure 4 ). This loss in monolayer can be attributed to the amount of bacteria that infected and survived in the macrophages during the first 18 hours of infection as well as the subsequent growth of the bacteria as seen by the average bacteria per cell (Figure 5). RV1985C showed a contribution to both aspects of colonization. RT-qPCR Analysis of $R v 1985 c$ during macrophage infection:

Cultured primary human macrophages were infected with H37Rv and total RNA was collected at time points $0,4,24$ hours post infection. cDNAs prepared from the isolated RNA was then analyzed by RT-PCR as described in Methods. The results showed an increase in $R v 1985 \mathrm{C}$ mRA levels after the first 24 hours post infection by approximately 15 fold over its expression in bacteria growing at mid-log in broth (Figure 6). This identifies $R v 1985 C$ as being expressed 
early after phagocytosis by resting primary human macrophages and suggests it may play a role in adaptation to this dynamic environment.

\section{Array Hybridization Rv1985c:}

During the course of infection $M$. tuberculosis encounters a wide range of environments and external stimuli. In response to these stimuli the bacterial transcriptome must be able to adapt and respond to ensure bacterial survival. Through previous work, done by Dr. Mohammad Alzohairy, the transcriptional regulator RV1985C was identified as belonging to a regulatory cascade initiated by the CpsA. Transcriptional regulator CpsA has been shown previously to be important for the pathogenesis of M. tuberculosis and, Rv1985C is one of only two transcriptional regulators absent from Bacille Calmette Guerin, BCG. I therefore attempted to identify RNAs whose expression was controlled by this transcriptional regulator.

The constitutively $R v 1985 \mathrm{C}$ expressing strain $(R V 1985 c+)$ was first analyzed to determine its increase in RV1985C mRNA levels. RT-qPCR indicated that the RV1985C constitutively expressing strain showed an approximately two-fold increase in its RV1985C mRNA level over that H37Rv wild type strain (Figure 7). This small increase was 
however significant as determined by Rest software (Pfaffl et al., 2002). The constitutively expressing strain was then grown to mid-log density and the RNA collected and purified. Approximately 25ug of DNAse treated RNA was the converted to radiolabeled CDNA and used for array analysis as described in the Methods section. The Rv1985C strain array hybridization was performed in triplicate and compared to three existing $\mathrm{H} 37 \mathrm{Rv}$ mid-log broth arrays. To compare different arrays (Figure 8) with different overall levels of hybridization, we determined the mean intensity for the 16 genomic DNA spots on each array (at corners and on mid-line). The individual spot intensity values for each array were then normalized by a ratio of its genomic spots to the average intensity for all genomic spots on all of the arrays compared. Analysis with BRB Array Tools, S.A.M., also applies a median normalization, where an algorithm chooses a reference array among all compared whose own median hybridization intensity signal is median among those compared. Individual gene intensities on each array are then normalized by subtracting the median difference among all features relative to the reference array. There were 30 ORFs determined to be significantly (Table 2) different between H37Rv and Rv1985C+ by significance analysis of microarray, S.A.M., with a 90th 
percentile confidence and the false discovery rate among the 30 significant ORFs set to 0.10 ; with 22 ORFs having increased expression and eight with decreased.

Of the 22 ORFs whose hybridization increased interestingly the largest increases were for $R V 1738$, fdxA, RV3131, \& hspx/acr. All of these have been previously described as being part of the DosR/DevR dormancy regulon (Voskuil 2003). Alpha-crystallin protein, Acr, encoded by acr has been shown to be expressed highly during hypoxic conditions, stationary growth phase as well as in nitric oxide enriched environments (Vasudeva-Rao et al., 2008). member of the small heat shock protein family, Acr forms high-molecular weight aggregates as well as having chaperone activity in vitro (Park et al., 2003). fdxA, which encodes ferredoxin $A$, is involved in an alternate pathway for electron transport (Voskuil et al., 2003). RV1738\& RV3131 encode conserved hypothetical proteins with no known function. Also noteworthy was the increased mRNA levels of desA2 (acyl-desaturase), desA3 (linoleoyl-CoA desaturase), and $f b p A$ (mycolyl-transferase, mediating permeability) as well as a decrease fabB (malonyl CoA-acyl carrier protein), fbpc2 (mycolyl-transferase), and acpM (meromycolate extension acyl carrier, involved in mycolic acid synthesis). We verified the increased $\mathrm{fdxA}$ and 
hspX/acr mRNA levels by RT-qPCR and confirmed the lack of increased $\operatorname{dos} R / \operatorname{dev} R$ transcription in the constitutively expressing $R v 1985 C$ strain (Figure 7 ). 
Figure 1 .

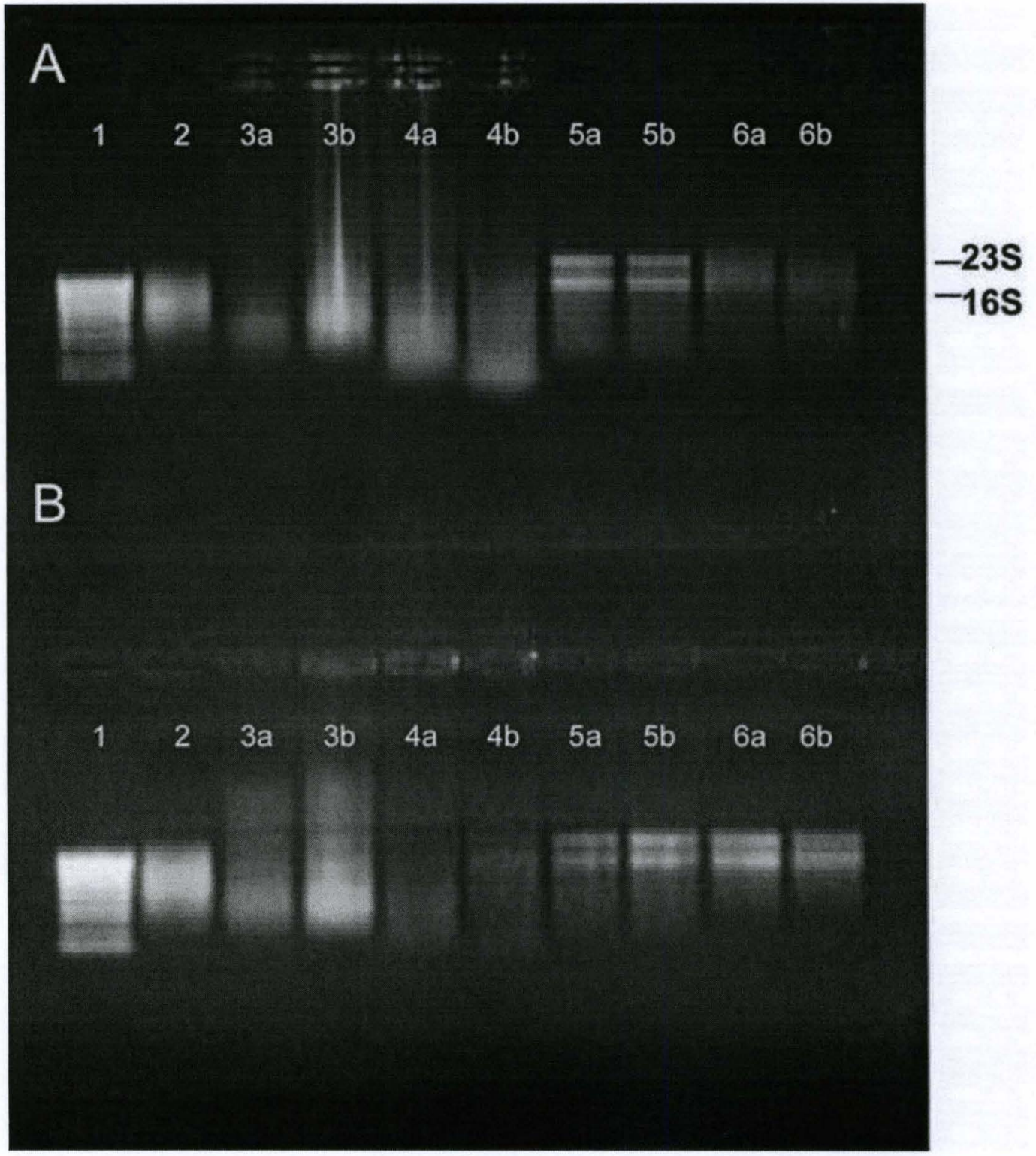


Figure 1. The figure shows RNA samples run on a nondenaturing agarose gel. Panel A lane one depicts a standard DNA ladder, lane 2 a bacteriophage MS2 RNA standard, lanes 3a \& 3b duplicate phenol-chloroform extractions, lanes $4 a \& 4 b$ phenol-chloroform extractions with DNase treatment, lanes $5 \mathrm{a} \& 5 \mathrm{~b}$ purification only by silica column binding, lanes $6 \mathrm{a} \& 6 \mathrm{~b}$ silica column binding with DNase treatment. Panel B shows parallel samples as listed above but after an additional precipitation by ethanol-ammonium acetate. RNA used for research described is shown in lanes $6 \mathrm{a}$ and $6 \mathrm{~b}$. 
Figure 2 .

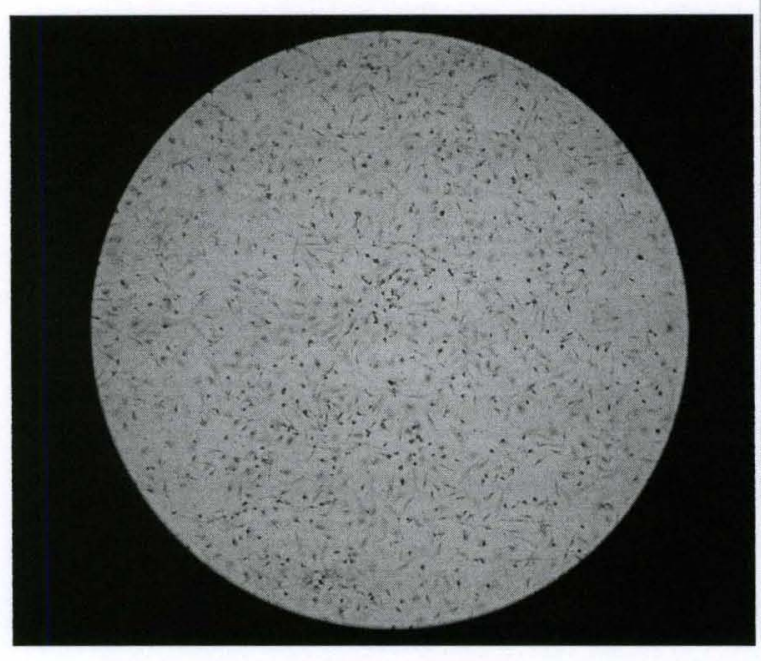

A

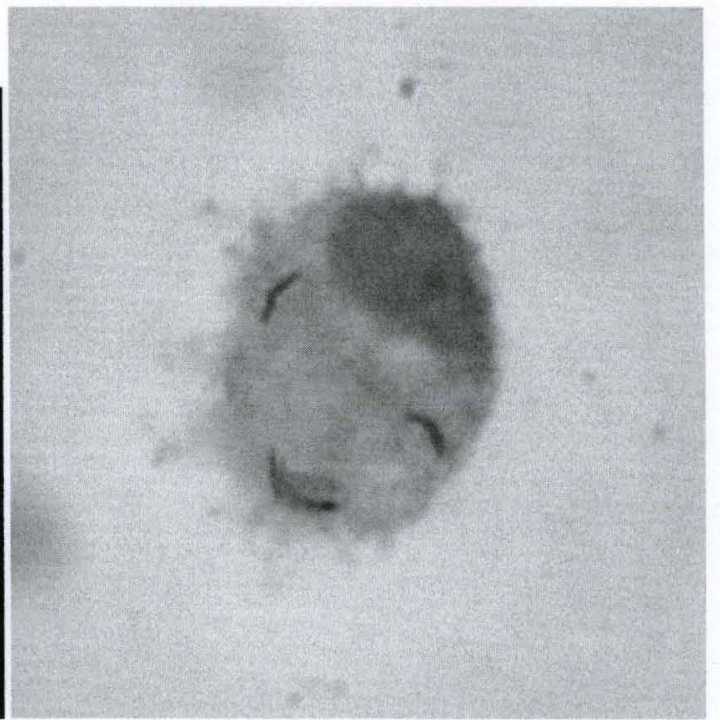

B

Figure 2. Human PBMC infection model. "Panel $A$ " shows a representative primary human macrophage monolayer prior to infection. "Panel B" shows a cold Kinyoun acid-fast staining of a single H37Rv-infected macrophage at 48 hours post infection. 
Figure 3 .

A

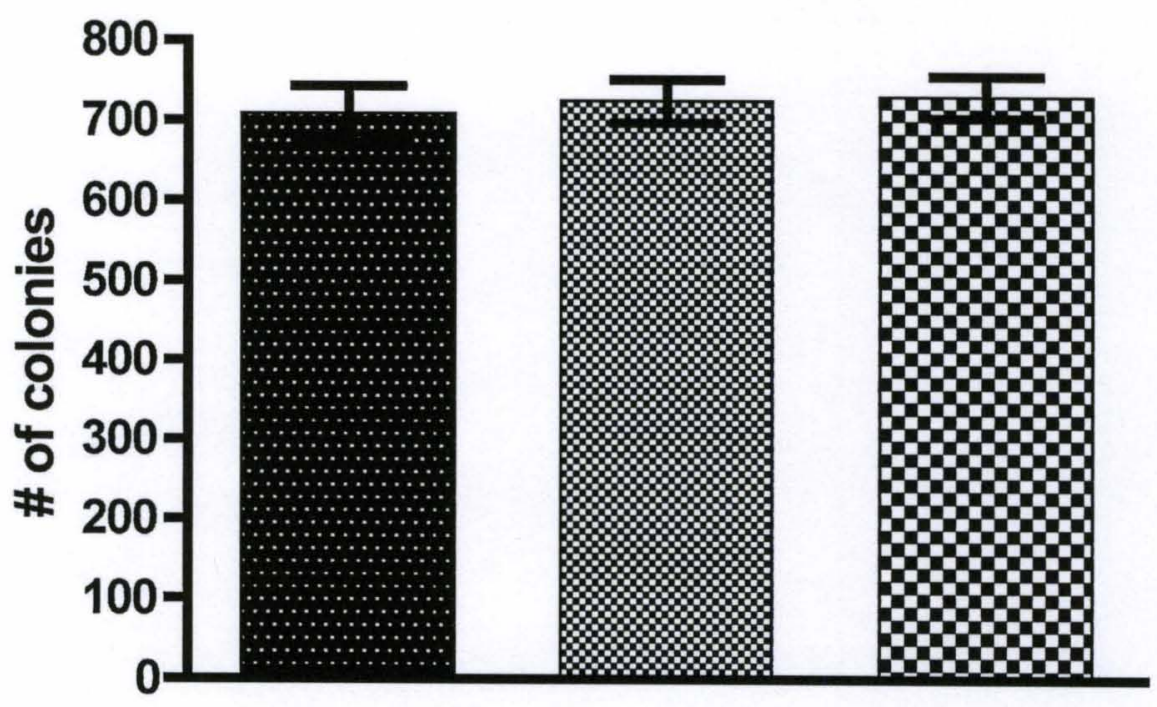

B

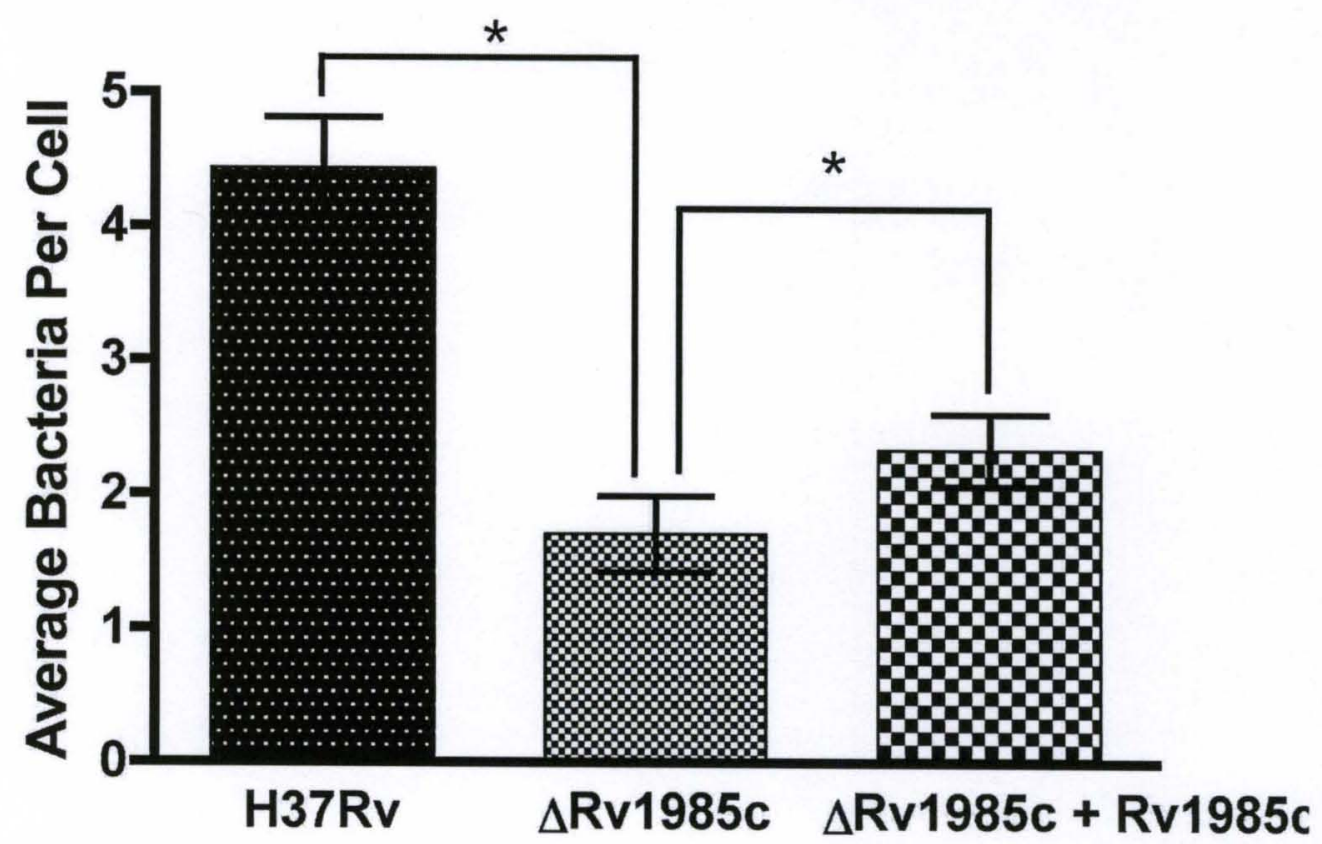


Figure 3. Rv1985c contributes to uptake and early intracellular survival. A) Shows similar numbers of mutant and isogenic H37Rv that were used as inoculum in the PBMC infection model described in Methods. Error bars show standard errors of mean plate counts from four independent dilutions of each inoculum. B) $\Delta R V 1985 C$ showed a significant reduction in uptake up and survival at 18 hours in primary human macrophages $\mathrm{p}<0.005$. The complemented strain showed incomplete restoration in intracellular survival at 18 hours. Error bars show standard errors of mean bacterial counts. 


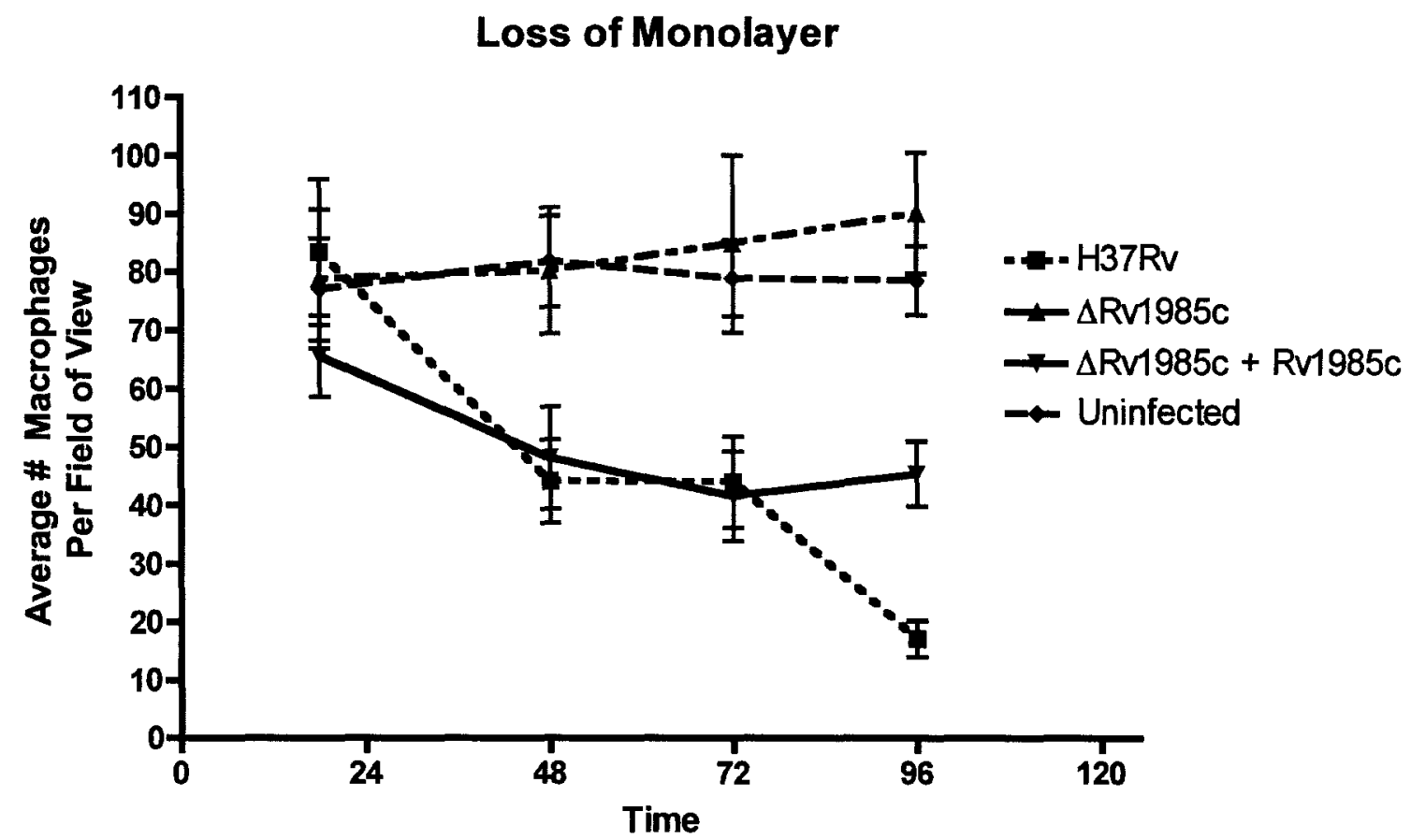

Figure 4. Cells infected by the Rv1985c mutant show better survival in the infection model. The reduced ability of the Rv1985c mutant to colonize cells and subsequent decreased growth rate resulted in improved survival of macrophage monolayers in the infection model. Restoring $R v 1985 C$ reversed this attenuation of the mutant. Error bars show standard errors of mean cell counts. 


\section{Bacteria Per Cell}

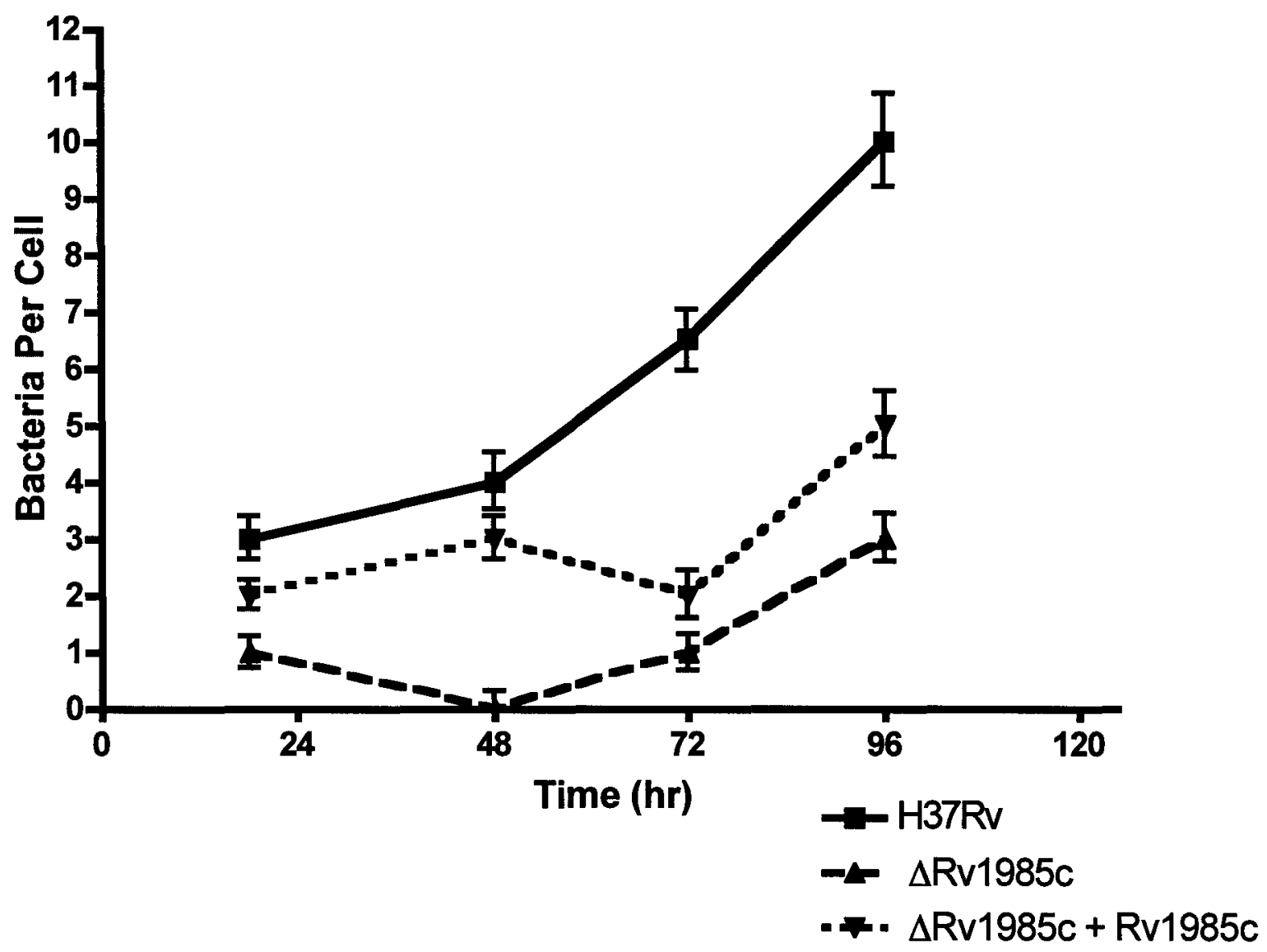

Figure 5. Rv1985c contributes to intracellular growth. The Figure shows the average bacteria per cell as determined by acid-fast staining and microscopy at the indicated time points. Error bars show standard errors of mean bacterial counts. 


\section{Macrophage Infection Time Course}

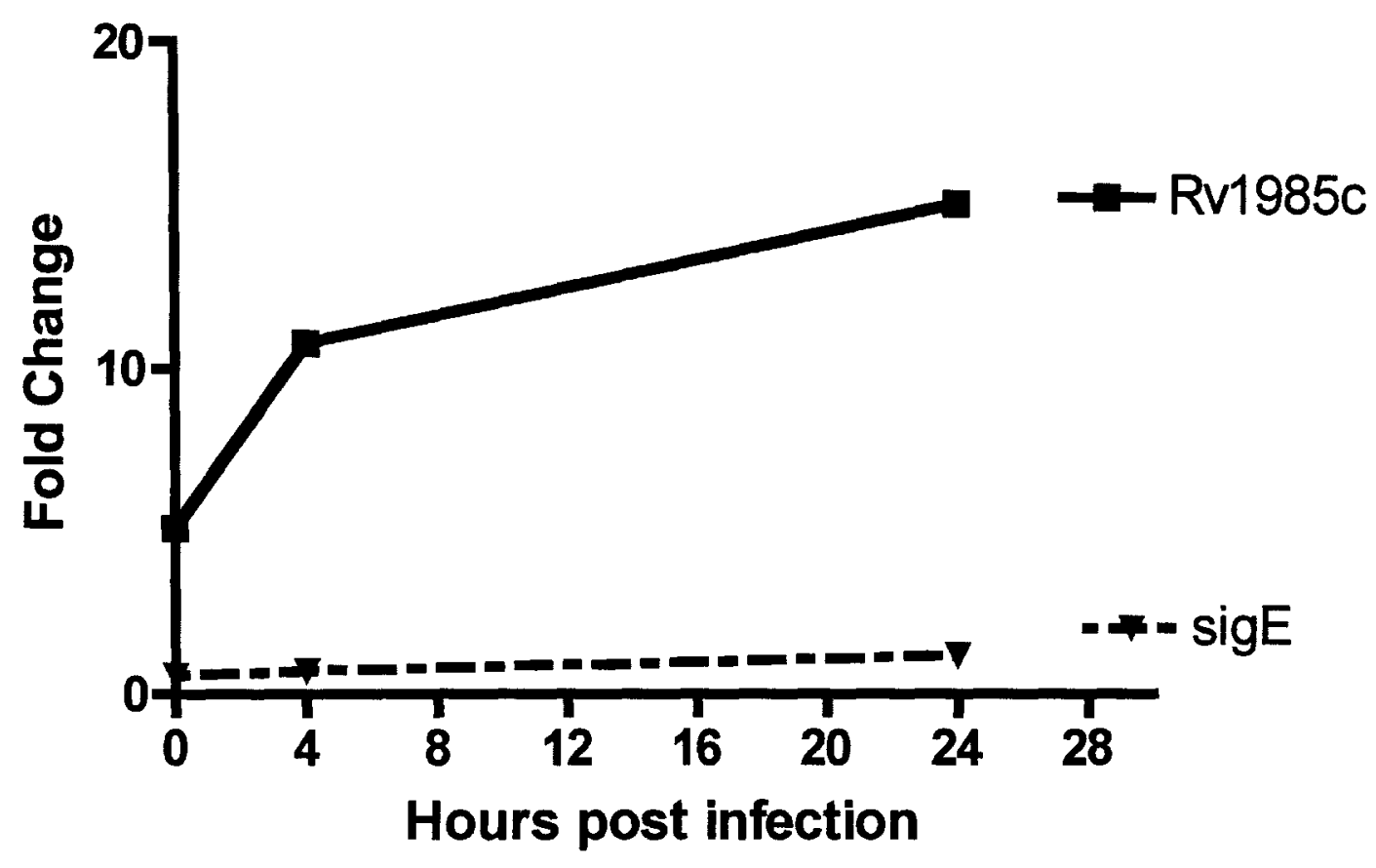

Figure 6. Rv1985c mRNA levels increase on phagocytosis. The Figure shows the results of RT-qPCR analysis of M. tuberculosis mRNA levels during the early time course of primary human macrophage infection. Changes in mRNA levels were determined by normalizing to sigA mRNA levels, and are shown relative to those in mid-log phase broth cultures. Changes in mRNA levels other than for sigE were determined to be significant by the REST software tool ( $p<0.05$ ) (Pfaffle, et al., 2005) 


\section{Rv1985c-full RNA Induction}

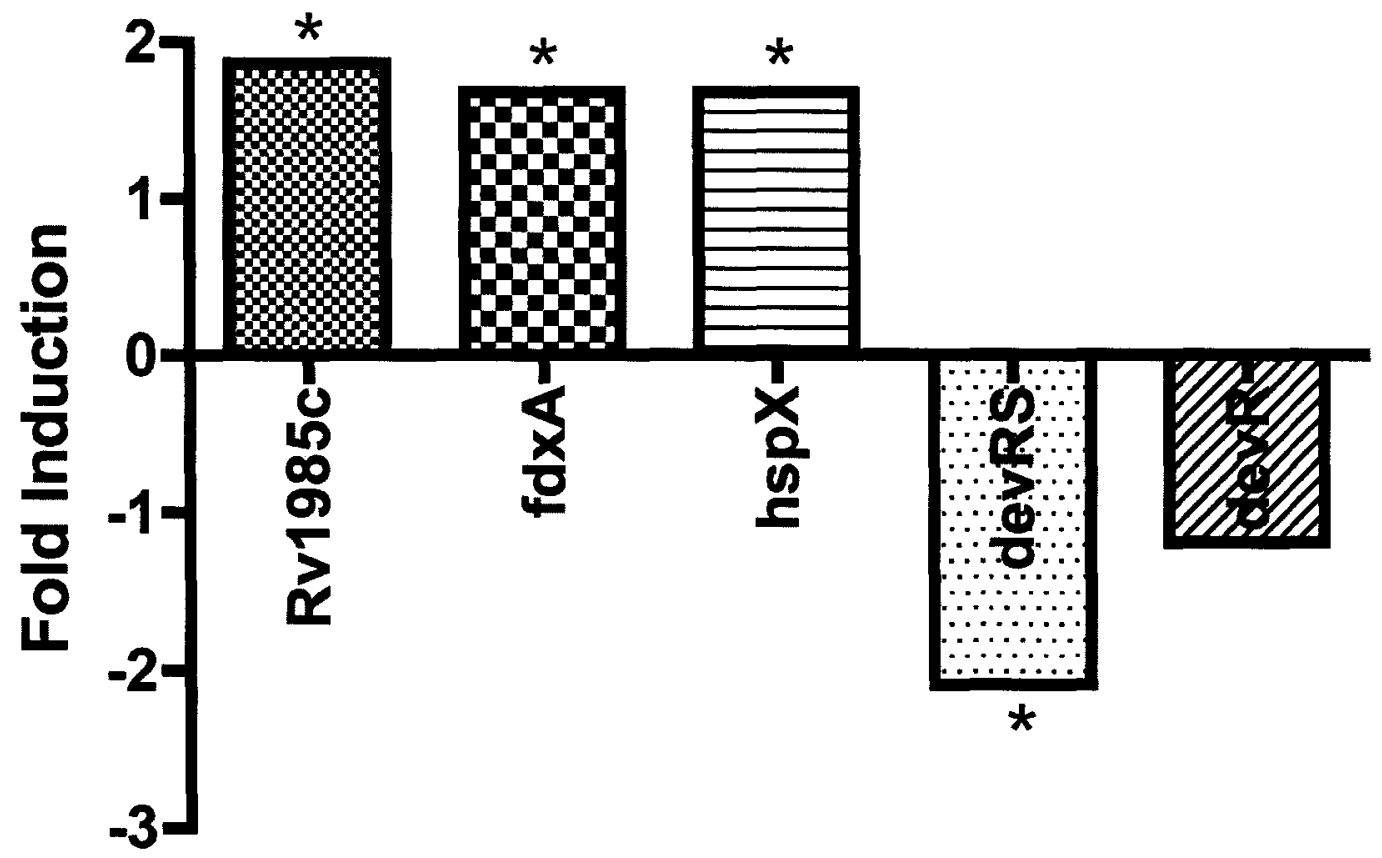

Figure 7. Changes in mRNA levels with constitutively expressed Rv1985C. The figure shows changes in relative mRNA steady-state levels for the indicated mRNAs relative to sigA. mRNAs levels were measured by RT-qPCR as described in Methods. Changes except for devR were determined to be statistically significant with a p-value of at least 0.005 , by REST software (Pfaffl et al., 2002). 
Figure 8 .

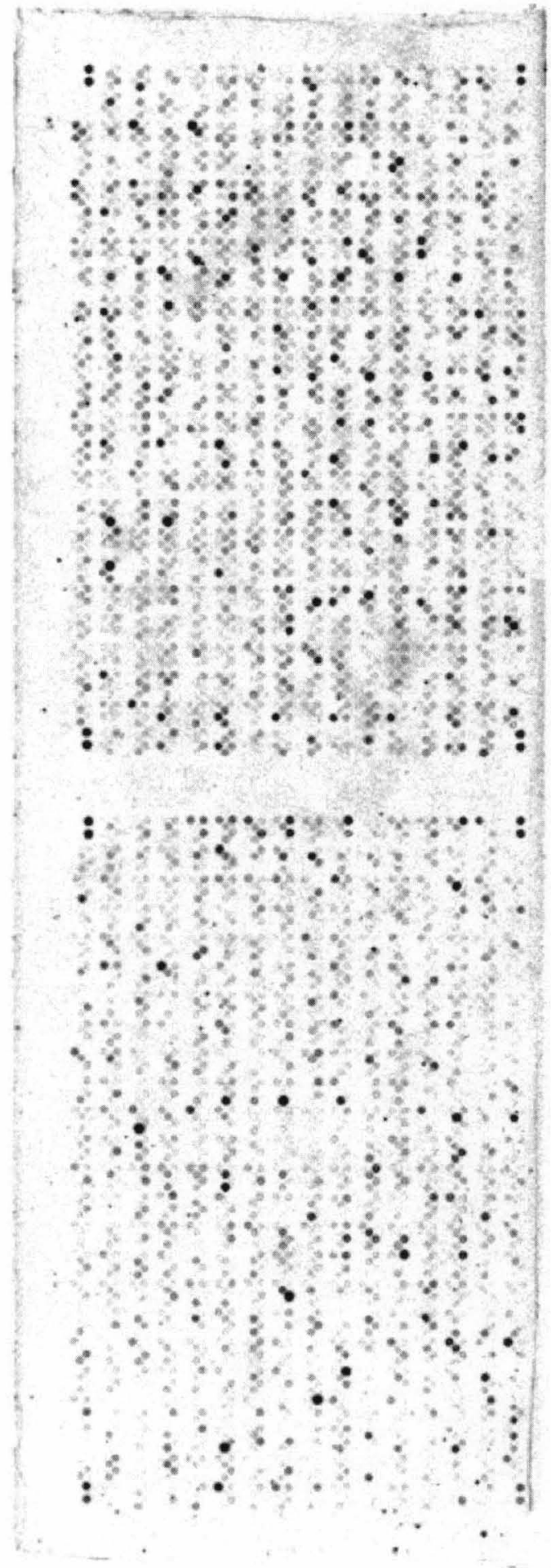


Figure 8. Representative array hybridization image. The array shown is hybridized with a $1^{\text {st }}$-strand cDNA probe prepared from H37Rv constitutively expressing Rv1985C grown to mid $\log$ in Middlebrook $7 \mathrm{H} 9$ OADC as described in Methods. 


\begin{tabular}{|c|c|c|c|c|}
\hline mRNA & annotation & H37Rv & $+R v 1985 c$ & fold-change \\
\hline$R v 1738^{*}$ & conserved hypothetical protein & 10 & 164 & 16 \\
\hline$f d x A^{*}$ & ferredoxin & 7 & 91 & 13 \\
\hline Rv3131* & conserved hypothetical protein & 10 & 87 & 9 \\
\hline$h s p X / a c r^{*}$ & heat shock protein & 8 & 68 & 8 \\
\hline$R v 0872 c$ & PE_PGRS-15 glycine rich protein & 6 & 50 & 8 \\
\hline Rv1059 & conserved hypothetical protein & 6 & 44 & 7 \\
\hline Rv3031 & conserved hypothetical protein & 14 & 93 & 7 \\
\hline hrp1 & putative inosine phosphate dehydrogenase & 10 & 64 & 6 \\
\hline Rv0109 & PE_PGRS-1 glycine rich protein & 10 & 61 & 6 \\
\hline$b f r B$ & bacterioferritin & 26 & 144 & 6 \\
\hline$R v 0079^{*}$ & hypothetical protein & 8 & 46 & 5 \\
\hline$R v 0829$ & is 6110 ' transposase & 33 & 170 & 5 \\
\hline Itp3 & lipid carrier protein & 16 & 81 & 5 \\
\hline Rv3489 & hypothetical protein & 45 & 219 & 5 \\
\hline$r p / C$ & ribosomal protein L3 & 53 & 242 & 5 \\
\hline Rv0047c & conserved hypothetical protein & 9 & 40 & 5 \\
\hline nusE & transcription elongation factor & 86 & 377 & 4 \\
\hline whiB1 & transcriptional regulatory protein & 38 & 165 & 4 \\
\hline $\operatorname{des} A 3$ & linoleoyl-coadesaturase & 9 & 37 & 4 \\
\hline$f b p A$ & mycolyl transferase & 107 & 435 & 4 \\
\hline $\operatorname{des} A 2$ & acyldesaturase & 21 & 82 & 4 \\
\hline Rv0195 & transcriptional regulatory protein & 15 & 54 & 4 \\
\hline Rv0232 & transcriptional regulatory protein & 24 & 6 & -4 \\
\hline$R v 2407$ & conserved hypothetical protein & 26 & 6 & -4 \\
\hline$f b p C 2$ & mycolyl transferase & 33 & 7 & -5 \\
\hline$f a b D$ & malonylcoa-acyl carrier protein & 32 & 6 & -5 \\
\hline groEs & 10k Da chaperonin & 135 & 23 & -6 \\
\hline acpM & meromycolate extension acyl carrier & 261 & 35 & -8 \\
\hline$R \vee 3388$ & pe-pgrs family protien & 243 & 25 & -10 \\
\hline$I p p Q$ & conserved lipoprotein & 84 & 6 & -14 \\
\hline
\end{tabular}


Table 2: List of mRNAs whose levels were significantly changed by constitutive Rv1985C expression. We used S.A.M. (significance analysis of microarrays) with 908 confidence and a false discovery rate set to 0.1 to identify differentially expressed genes. Asterisk indicates members of the previously described DosR/DevR regulon (Voskuil el, $2009)$. 
CHAPTER IV

\section{DISSCUSSION}

\section{Desaturases and Mycolic Acid Modification:}

Mycolic acids are beta-hydroxy fatty acids with a long alpha-alkyl side chain $(60-80 \mathrm{C})$ found in the cell wall of M. tuberculosis (Takayama et al., 2005). Mycolic acids can help the bacteria resist chemical and oxidative damage and help the bacteria survive inside host macrophages (Todar, 2011). There are only three acyl-desaturases in the $\mathrm{H} 37 \mathrm{Rv}$ genome DesA1, DesA2, and DesA3. Acyl-desaturase, desA2, works outside the cell by introducing double bonds to mycolic acid precursors altering side chains.

Interestingly desA2 requires a ferredoxin to transfer electrons from NADH or NADPH for its bond forming activity. While no specific ferredoxin has been identified in this process FdxA has been shown to be a potential candidate (Chang, 2009). We also saw an increase in bfrB mRNA levels, whose encoded product a bacterioferritin, may provide iron necessary for FdxA synthesis and activity. DesA3 (linoleoyl-COA desaturase) is involved in the production of a major component of membrane phospholipids and triglycerides, oleic acid. It is also considered one 
of approximately 200 genes necessary for survival of M. tuberculosis inside a granuloma (Chang, 2009). Its role in this process, like that of desA2, is centered around modification of the cell membrane and wall. Also, it is worthy to note that desaturases, DesA2 and DesA3 are shortlived enzymes with relatively unstable mRNA and under constant transcriptional control (Chang, 2009).

Finally, the decrease in expression of mRNA of fabB (malonyl CoA-acyl carrier protein) and acpM (meromycolate extension acyl carrier), which are essential in the synthesis of mycolic acids (Barry et al., 1998) coupled with the increase in desA2 transcription suggests a switch from mycolic acid synthesis to the remolding of existing mycolic acids.

\section{fbpA and fbpc2:}

FbpA and Fbpc2 are two of three mycolyl-transferase paralogs long considered the $M$. tuberculosis "antigen 85 complex". Their role consists of transfer of mycolates to arabinogalactans on the exterior of the cell wall required for maintaining the integrity of the bacterial cell envelope (Puech et al., 2002). By constitutively expressing Rv1985c, the steady state mRNA level of fbpA mRNA goes up while the steady state level of fpbc2 goes down. According to Puech et al, 2002 a decrease in the 
expression of $f p b c 2$ can lead to increased cell

permeability. Modifications to the cell wall can lead to increased permeability for new nutrients or decreased to avoid host factors. Paralogs may perform slightly different activities but are particularly useful for fine tuning regulated expression from alternate promoters under conditions of environmental signals.

\section{Alpha-crystallin:}

Alpha-crystallin has been shown to be required for M. tuberculosis to grow optimally within macrophages. Also, during bacterial stress Acr localizes to the cell wall and membrane (Quinn et al., 2002). It may also act on other proteins to aid in maintaining stability (Quinn et al., 2002). The location and activity suggests a protective role of alpha-crystallin not only for the cell as a whole but potentially for mycolic acid modification going on outside the cell.

\section{Rv1985c may bind dnaA:}

In a late 2010 paper $\mathrm{zhou}$ et al. determined the crystal structure of Rv1985c protein and showed that it can bind to DNA and prevent helix opening at oric in vitro; thus preventing replication. In vivo they speculate that RV1985c may have a dual role, and act as a marker of physiological circumstance by activating dnaA during times 
of good nutrition to accelerate growth or conversely inhibit chromosomal replication during non-favorable circumstances (zhou et al., 2010). I did not see any reduced growth with constitutive Rv1985C expression. Further experiments will be needed to confirm this proposed activity and determine if it requires additional factors not present at mid-log phase in laboratory cultures Increased $R v 1985 C$ expression in response to Phagocytosis: Rv1985C is highly expressed during the first 24 hours following phagocytosis by primary human macrophages. This timing of expression coincides with a drastic change in the environment when there would need to be a change in the mycolic acids on the outside of the cell as well as increasing the cells ability to deal with a more stressful environment. The specific mechanisms suggested by the RNA expression and mutant studies described will need to be characterized by directed experiments.

\section{Future Experiments:}

Future experiments will include the verification of the increase in expression of $\operatorname{des} A 2 \& \operatorname{des} A 3$ as well as the decrease in expression of $\mathrm{fabB}$ and acpM by RT-qPCR. Also I will attempt to demonstrate the modification of mycolic acid by solvent extraction and mass spectronomy and by a neutral-red cytochemical reaction. Finally, chromatin 
immunoprecipitation assay, ChIP, of Rv1985c will be utilized to confirm the binding sites of Rv1985c to the DNA operator regions and determine direct and indirect roles in transcriptional regulation during intracellular adaptation Conclusion:

The aforementioned studies show a contribution of Rv1985c to the intracellular adaptation of $M$. tuberculosis. They indicate modifications to mycolic acids and the cell membrane of the bacteria that may contribute to the ability to survive and grow in primary human macrophages. 


\section{REFERENCES}

Barry, C. E., Lee, R. E., Mdluli, K., Sampson, A. E., Schroeder, B. G., Slayden, R. A. et al. (1998). Mycolic acids: structure, biosynthesis and physiological functions. Progress in lipid research, 37(2-3), 143-179.

Camus, J. C., Pryor, M. J., Medigue, C., \& Cole, S. T. (2002). Re-annotation of the genome sequence of Mycobacterium tuberculosis H37Rv. Microbiology, 148(Pt 10), 2967-2973.

Chang, Y. (2009). Studies of Mycobacterium tuberculosis Desaturases and Their Electron Transfer Partners. Doctor of Philosophy University of WisconsinMadison.

Chauhan, S., \& Tyagi, J. S. (2008). Interaction of DevR with multiple binding sites synergistically activates divergent transcription of nark2-Rv1738 genes in Mycobacterium tuberculosis. J Bacteriol, 190(15), $5394-$ 5403. doi: $10.1128 /$ JB. $00488-08$

Chauhan, S., Sharma, D., Singh, A., Surolia, A., \& Tyagi, J. S. (2011). Comprehensive insights into Mycobacterium tuberculosis DevR (DosR) regulon activation 
switch. Nucleic Acids Res,. doi:10.1093/nar/gkr375 Chen, J., Wang, S., Zhang, Y., Su, X., Wu, J., Shao, L. et al. (2010). Rv1985c, a promising novel antigen for diagnosis of tuberculosis infection from BCG-vaccinated controls. BMC Infect Dis, 10, 273. doi:10.1186/1471-2334$10-273$

Cole, S. T., Brosch, R., Parkhill, J., Garnier, T., Churcher, C., Harris, D. et al. (1998). Deciphering the biology of Mycobacterium tuberculosis from the complete genome sequence. Nature, 393(6685), 537-544. doi $: 10.1038 / 31159$

Flynn, J. L., \& Chan, J. (2001). Tuberculosis: latency and reactivation. Infect Immun, 69(7), 4195-4201. doi: 10.1128/IAI.69.7.4195-4201.2001

Gerasimova, A., Kazakov, A. E., Arkin, A. P., Dubchak, I., \& Gelfand, M. S. (2011). Comparative genomics of the dormancy regulons in Mycobacteria. Journal of Bacteriology, $193(14), 3446$.

Graham, J. E., Wantland, N. B., Campbell, M., \& Klotz, M. G. (2011). Characterizing bacterial gene expression in nitrogen cycle metabolism with RT-qPCR. Methods Enzymol, $496,345-372$. doi: $10.1016 /$ B978-0-12-386489-5.00014-2

Kozak, R. A., Alexander, D. C., Liao, R., Sherman, D. R., \& Behr, M. A. (2011). Region of difference 2 
contributes to virulence of Mycobacterium tuberculosis. Infect Immun, 79(1), 59-66. doi:10.1128/IAI.00824-10

Leistikow, R. I., Morton, R. A., Bartek, I. L., Frimpong, I., Wagner, K., \& Voskuil, M. I. (2010). The Mycobacterium tuberculosis DosR regulon assists in metabolic homeostasis and enables rapid recovery from nonrespiring dormancy. J Bacteriol, 192(6), 1662-1670. doi : $10.1128 /$ JB. 00926-09

Li, A. H., Lam, W. L., \& Stokes, R. W. (2008). Characterization of genes differentially expressed within macrophages by virulent and attenuated Mycobacterium tuberculosis identifies candidate genes involved in intracellular growth. Microbiology, 154(Pt 8), 2291-2303. doi : 10.1099/mic.0.2008/019661-0

Manganelli, R., Provvedi, R., Rodrigue, S., Beaucher, J., Gaudreau, L., \& Smith, I. (2004). Sigma factors and global gene regulation in Mycobacterium tuberculosis. $J$ Bacteriol, 186(4), 895-902.

Manganelli, R., Provvedi, R., Rodrigue, S., Beaucher, J., Gaudreau, L., \& Smith, I. (2004). Sigma factors and global gene regulation in Mycobacterium tuberculosis. $J$ Bacteriol, 186(4), 895-902.

Park, H. D., Guinn, K. M., Harrell, M. I., Liao, R., Voskuil, M. I., Tompa, M. et al. (2003). Rv3133c/dosR is a 
transcription factor that mediates the hypoxic response of Mycobacterium tuberculosis. Mol Microbiol, 48(3), 833-843.

Parsons, L. M., Somoskovi, A., Gutierrez, C., Lee, E., Paramasivan, C. N., Abimiku, A. et al. (2011). Laboratory diagnosis of tuberculosis in resource-poor countries: challenges and opportunities. Clin Microbiol Rev, 24(2), 314-350. doi : 10.1128/CMR. 00059-10

Pfaffl, M. W., Horgan, G. W., \& Dempfle, L. (2002). Relative expression software tool (RESTO) for group-wise comparison and statistical analysis of relative expression results in real-time PCR. Nucleic acids research, 30(9), e36.

Puech, V., Guilhot, C., Perez, E., Tropis, M., Armitige, L. Y., Gicquel, B. et al. (2002). Evidence for a partial redundancy of the fibronectin-binding proteins for the transfer of mycoloyl residues onto the cell wall arabinogalactan termini of Mycobacterium tuberculosis. Mol Microbiol, 44(4), 1109-1122.

Russell, D. G. (2001). Mycobacterium tuberculosis: here today, and here tomorrow. Nat Rev Mol Cell Biol, 2(8), 569-577. doi: $10 \cdot 1038 / 35085034$

Quinn, F. D., Birkness, K. A., \& King, P. J. (2002). Alpha-crystallin as a potential marker of Mycobacterium tuberculosis latency. ASM News, 68(12). 
Schnappinger, D., Ehrt, S., Voskuil, M. I., Liu, Y., Mangan, J. A., Monahan, I. M. et al. (2003). Transcriptional Adaptation of Mycobacterium tuberculosis within Macrophages: Insights into the Phagosomal Environment. J Exp Med, 198(5), 693-704. doi: $10.1084 /$ jem. 20030846

Stewart, G. R., Robertson, B. D., \& Young, D. B. (2003). Tuberculosis: a problem with persistence. Nat Rev Microbiol, 1(2), 97-105. doi:10.1038/nrmicro749

Takayama, K., Wang, C., \& Besra, G. S. (2005). Pathway to synthesis and processing of mycolic acids in Mycobacterium tuberculosis. Clinical microbiology reviews, $18(1), 81$.

Todar, Kenneth (2011). Mycobacterium Tuberculosis and Tuberculosis. Textbook of Bacteriology.

Vasudeva-Rao, H. M., \& MCDonough, K. A. (2008). Expression of the Mycobacterium tuberculosis acrcoregulated genes from the DevR (DosR) regulon is controlled by multiple levels of regulation. Infect Immun, $76(6), 2478-2489$. doi:10.1128/IAI.01443-07

Volpe, E., Cappelli, G., Grassi, M., Martino, A., Serafino, A., Colizzi, V. et al. (2006). Gene expression profiling of human macrophages at late time of infection with Mycobacterium tuberculosis. Immunology, 118(4), 449- 
460. doi: $10.1111 / j .1365-2567.2006 .02378 . x$

Voskuil, M. I., Schnappinger, D., Visconti, K. C.,

Harrell, M. I., Dolganov, G. M., Sherman, D. R. et al.

(2003). Inhibition of respiration by nitric oxide induces a Mycobacterium tuberculosis dormancy program. J Exp Med, 198(5), 705-713. doi:10.1084/jem.20030205

Wayne, L. G., \& Hayes, L. G. (1996). An in vitro model for sequential study of shiftdown of Mycobacterium tuberculosis through two stages of nonreplicating persistence. Infect Immun, 64(6), 2062-2069.

Wayne, L. G., \& Sohaskey, C. D. (2001). Nonreplicating persistence of mycobacterium tuberculosis. Annu Rev Microbiol, 55, 139-163. doi:10.1146/annurev.micro.55.1.139

World Health Organization. (2011). Tuberculosis. > http://www. who.int/mediacentre/factsheets/fs104/en/index.ht ml>.

Yuan, Y., Crane, D. D., Simpson, R. M., Zhu, Y. Q., Hickey, M. J., Sherman, D. R. et al. (1998). The 16-kDa alpha-crystallin (Acr) protein of Mycobacterium tuberculosis is required for growth in macrophages. Proc NatI ACad Sci U S A, 95(16), 9578-9583.

Zhou, X., Lou, Z., Fu, S., Yang, A., Shen, H., Li, z. et al. (2010). Crystal structure of ArgP from Mycobacterium tuberculosis confirms two distinct conformations of full- 
length LysR transcriptional regulators and reveals its

function in DNA binding and transcriptional regulation. $J$

Mol Biol, 396(4), 1012-1024. doi:10.1016/j.jmb.2009.12.033 


\section{CURRICULUM VITAE}

\begin{tabular}{|c|c|}
\hline NAME : & Nicholas B. Wantland \\
\hline ADDRESS : & $\begin{array}{l}1822 \text { Allanwood Road } \\
\text { Louisville, KY } 49214\end{array}$ \\
\hline DOB : & Louisville, Kentucky - August 19, 1984 \\
\hline \multirow[t]{2}{*}{ EDUCATION : } & $\begin{array}{l}\text { B.S. Biology } \\
\text { University of Louisville } \\
\text { Louisville, Kentucky } \\
2006\end{array}$ \\
\hline & $\begin{array}{l}\text { DeSales High School } \\
\text { Louisville, Kentucky } \\
2002\end{array}$ \\
\hline AWARDS : & $\begin{array}{l}\text { Harvard Prize Book } \\
\text { Commonwealth Scholarship }\end{array}$ \\
\hline PUBLICATIONS : & $\begin{array}{l}\text { James E. Graham, Nicholas B. Wantland, Mark } \\
\text { A. Campbell, and Martin G. Klotz. } 2011 \text {. } \\
\text { Characterizing bacterial gene expression in } \\
\text { nitrogen cycle metabolism with RT-qPCR. In: } \\
\text { Research on Nitrification and Related } \\
\text { Processes, Part B. Methods in Enzymology, } \\
\text { Vol. } 496, \text { Pages } 345-372\end{array}$ \\
\hline
\end{tabular}

